\title{
Osmanlı Döneminde (1915-1918) Bandırma-İstanbul Deniz Ulaşımı ve Vapur Yolcu Listeleri
}

\author{
Cengiz Şekera, b, Engin Çağmanc
}

Özet

Bandırma, coğrafi konumu ve denizyoluyla İstanbul'a yakınlığı nedeniyle özellikle Osmanlı Devleti'nin son döneminde büyük önem kazanmıştır. Bandırma-İstanbul denizyolu daha önce de kullanılmakla birlikte modern dönemde bu kullanım gittikçe yoğunlaşan bir seyir izlemiş ve bu durum Bandırma kenti ve limanının daha işlevsel hale gelmesini sağlamıştır. Başta gıda maddeleri olmak üzere İstanbul'un çeşitli ihtiyaçlarının karşılanması hususunda Bandırma'dan sağlanan mallardaki artışa paralel olarak Bandırma-İstanbul arası vapur seferlerinin yanı sıra yolcu sayısında da artış kaydedilmiştir. 19. yüzyılın sonlarına doğru Bandırma limanının verilen hizmetler açısından yetersiz kalması nedeniyle; iskelenin büyütülmesi, limandaki hizmet alanlarının genişletilmesi ve gece seferlerindeki riski ortadan kaldırmak amacıyla belirli yerlere deniz fenerleri inşa edilmesi gibi bazı inşa ve imar faaliyetleri yapılmıştır. Bu çalışma, Bandırma-İstanbul denizyolunun Osmanlı dönemindeki önemine dikkat çekmeyi ve 1915-1918 yılları arasında Bandırma'dan İstanbul'a sefer yapan vapurlara ait yolcu listelerini analiz etmeyi hedeflemektedir. Listelerin yer aldığı belgeler sayıca az olmasına ve bir seri teşkil etmemesine rağmen yolcuların kimlikleri, meslekleri, nereden geldikleri ve İstanbul'da nerede konaklayacakları gibi bilgileri içermesi açısından önem arz etmektedir. Makalede söz konusu bilgiler tasnif edilmiş, mümkün olduğu ölçüde sayısal verilere dönüştürülmüş ve 1915-1918 yılları arasında Bandırmaİstanbul denizyolu güzergâhını kullanan yolcularla ilgili iktisadi ve sosyolojik bazı değerlendirmeler yapılmaya çalışılmıştır.
Anahtar Kelimeler

Bandirma

İstanbul

Deniz Taşımacılığı

Vapur Yolcu Listeleri

Makale Hakkında

Geliş Tarihi: 29.10.2020

Kabul Tarihi: 25.12.2020

Doi: $10.18026 /$ cbayarsos.818097

\section{Sea Transportation between Bandırma-Istanbul and Ferry Passenger Lists During the Ottoman Period (1915-1918)}

\begin{abstract}
Bandirma has risen into prominence notably during the Late Ottoman Empire due to its geographical location and its proximity to Istanbul through the sea. Although the Bandirma-Istanbul sea route had been active before, it became increasingly busier during the modern period and Bandırma, along with its port became more utilized. The ferry traffic and passengers travelling between Bandirma-Istanbul soared in parallel with an increase in the goods supplied from Bandirma to meet the various needs of Istanbul, chiefly foodstuffs. Toward the end of the 19th century, the port of Bandirma had undergone several constructional developments to address insufficient port facilities. Accordingly, the pier was extended, service areas were expanded, and lighthouses were built in certain places to eliminate the risk of night trips. The present study aims to draw attention to the importance of the Bandirma-Istanbul sea route during the Ottoman period and to analyze the passenger lists of the ferries that sailed between these cities in 1915-1918. Although documents containing such lists are few and do not constitute a series, they offer significant information as to the passengers' identities, occupations, residences, and accommodations in Istanbul. The study sorted such information, converted them into numerical data where possible, and attempted an economical and sociological evaluation of the passengers using the BandirmaIstanbul sea route between 1915-1918.
\end{abstract}

Keywords

Bandirma

İstanbul

Sea Transportation

Ferry Passenger Lists

About Article

Received: 29.10.2020

Accepted: 25.12.2020

Doi: 10.18026/cbayarsos. 818097

a İletişim Yazarı: cseker@bandirma.edu.tr

b Dr. Öğr. Üyesi, Bandırma Onyedi Eylül Üniversitesi İTBF Tarih Bölümü ORCID: 0000-0001-5737-4914

c Dr. Öğr. Üyesi, Bandırma Onyedi Eylül Üniversitesi IÏBF İktisat Bölümü, ORCİD: 0000-0002-4733-8418 


\section{Giriș}

Yazının konusunu Osmanlı Devleti'nin son döneminde Bandırma-İstanbul denizyolu ulaşımı (1) ile 1331-1334 (1915-1918) yılları arasında Bandırma'dan İstanbul'a seyr ü sefer yapan bazı vapurlara ait yolcu listeleri teşkil etmektedir. Bu listelerin incelenmesinden önce birinci bölümde Bandırma-İstanbul deniz yolu ulaşımının modern dönemde gittikçe artan önemine değinilmiştir.

Bir liman kenti olması ve geniş hinterlandı sayesinde Bandırma'nın tarihi antik dönemlere kadar uzanmaktadır. Osmanlı döneminde de önemini koruyan Bandırma özellikle 19. yüzyıldan itibaren İstanbul'un temel ihtiyaçlarının karşılanmasında çok önemli fonksiyonlar icra etmiştir. Kentin giderek artan yoğunluğu nedeniyle dönemin yetkilileri denizyolu ulaşımının geliştirilmesi ve limanın ve gümrük binasının ihtiyaca cevap verecek hale getirilmesi için bazı yatırımlar yapmıştır. Yanı sıra 1912'de işletmeye açılan BalıkesirBandırma demiryolu ile birlikte sağlanan demiryolu-denizyolu entegrasyonu kentin ve bölgenin kalkınmasına önemli faydalar sağlamıştır.

Çalışmanın ikinci bölümünde, 17 Nisan 1331 (30 Nisan 1915)-10 Teşrin-i sani 1334 (10 Kasım 1918) tarihleri arasında vapurla Bandırma'dan İstanbul'a seyahat eden yolculara ait bazı listeler ele alınmıştır. Bu listelerde yolcuların isimleri, yaşları, cinsiyetleri, memleketleri, uyrukları, meslekleri, nereden geldikleri ve İstanbul'da nerede konaklayacakları belirtilmektedir. Yazıda bu sınırlı bilgilerden yola çıkarak bazı istatistikler vermeye, listelerdeki bilgileri derlemeye ve aralarında anlamlı ilişkiler kurmaya çalıştık. Belgelerin farklı tarihlerde olması, yani yolcu listelerinin düzenli tutulmaması veya en azından Osmanlı arşivlerinde -şimdilik- daha fazla liste bulunmaması amacımızın gerçekleşmesini oldukça zor hale getirmektedir. İlerde konuyla ilgili yeni arşiv belgelerinin bulunması durumunda daha anlamlı ve kesine yakın bilgilerin ortaya koyulması mümkün hale gelebilecektir.

\section{Yöntem}

Çalışmanın birinci bölümünde Osmanlı Devleti'nin son döneminde Bandırma'nın artan önemi ve Bandırma-İstanbul denizyolu Osmanlı arşiv belgelerinden istifadeyle ele alınmıştır. İkinci bölümde ise Bandırma-İstanbul vapur yolcularını içeren listeler değerlendirilmiştir. Bu değerlendirmede istatistik yöntemi kullanılmıştır. Yolcuların isimlerinden Müslim-gayrı Müslim sayıları tespit edilmiştir. Yine listelerin çoğunda yolcuların Bandırma'ya nereden geldiği belirtildiği için Bandırma'da ikamet edenlerle etmeyenler ve bunlarla ilgili bilgiler ayrıştırılabilmiştir. Yolcuların meslekleri de kaydedilmiş olduğundan bu alandaki bilgiler kategorize edilmiştir. Benzer şekilde yolcuların İstanbul'da konakladıkları yerler belirli olduğundan bu mekânların hane, otel ve hanlar olarak dağılımı yapılmıştır. Böylece elde edilen bilgiler anlamlı ilişkilere dönüştürülmüştür. Sözgelimi yolcuların ikamet için nereleri tercih ettiği, yolculukların dini gruplara ve cinsiyetlere göre dağılımı ve yolculukların ne amaçla yapıldığı gibi bilgilere ulaşılmaya çalışılmıştır.

\section{Bulgular}

Osmanlı arşiv belgeleri, coğrafi konumu nedeniyle zaten antik dönemden itibaren önemli bir merkez olan Bandırma'nın bu öneminin Osmanlının modern döneminde bilhassa İstanbul'un bazı temel ihtiyaçlarının karşılanması açısından giderek arttı̆̆ını ortaya koymaktadır. Bu nedenle Bandırma-İstanbul denizyolunda hem mal hem de insan hareketliliği yoğunluk kazanmıştır. 
Bandırma-İstanbul arasında seyahat eden vapur yolcularına ait listelerin değerlendirilmesi sonucunda Bandırma'dan İstanbul'a giden yolcuların çoğunlukla Bandırma'da ikamet ettikleri, bununla birlikte muhtelif bölgelerden kişilerin de İstanbul'a gitmek üzere Bandırma'ya geldiği anlaşılmıştır. Vapur yolcularının ekseriyetini tüccarlar oluşturmaktadır. Ardından öğrenciler, üst düzey bürokratlar, memurlar, bakkallar ve rençberler gelmektedir. Konaklama için tercih edilen yerler haneler, oteller ve hanlardır. Hanelerin çok az bir bölümü burada kalan yolculara aittir. Yolcuların kaldığı mekânlar ile statüleri ve ekonomik durumları arasında açık ve net bağlar kurulamamıştır. Dini gruplar ve icra ettikleri meslekler arasında da benzer sonuca ulaşılmıştır. Yolcular arasında tüccar sayısının fazla olması, hanelerin büyük çoğunluğunun gelenlere ait olmaması, konaklama için hanelerin dışında otel ve hanların da yoğun olarak tercih edilmesi ve yolcuların ekseriyetle Bandırmalı olması seyahatlerin kısa süreliğine ve daha çok iktisadi amaçlarla yapıldığını düşündürmektedir. Bu durum Osmanlı Devleti'nin son döneminde Bandırma-İstanbul arasında ekonomik faaliyetlerin arttı̆̆ını teyit etmektedir.

\section{Modern dönemde Bandırma-İstanbul denizyolu}

Bandırmayla ilgili ilk kesin bilgiler MÖ. 7. yüzyılda kurulmuş olan Cyzikos şehrine ait olmakla birlikte kentin tarihi çok daha eski dönemlere kadar gitmektedir. İonya, Atina, Pers, Makedonya ve Roma gibi birçok uygarlığın istilasına uğrayan kent, 297 yılında 33 şehri içine alan Hellespontos vilayetinin merkezi olmuştur. Hiristiyanlığın kabulünden itibaren Metropolitlik merkezi olarak kabul edilmiş ve bu konumu Hellespontos ve Asya Metropoliti olarak 20. yüzyıl başlarına kadar devam etmiştir. (Üçışık, 1998: 38-40) Öte yandan körfezin avantajlı konumundan dolayı Bandırma'da liman ve denizcilik faaliyetleri tarih boyunca süreklilik arz etmiştir. Roma döneminde Batı Anadolu'da kurulan yol şebekesi ile birlikte Marmara Denizi'nin önemli limanlarından biri haline gelen Bandırma, Bizans ve Osmanlı dönemlerinde de bu önemini korumuştur. (Üçışık, 123)

Bandırma, Osmanlı Devleti'nin 19. yüzyılda Balkan topraklarını kaybetmesiyle daha çok önem kazanmış ve İstanbul'un birçok temel ihtiyacının karşılandığı bir merkez olmuştur. Karayolu ulaşımına kıyasla denizyolu ulaşımının avantajlı olması nedeniyle temel gıda maddeleri, sınai ürünler ve yer altı kaynaklarının İstanbul'a sevkiyatında Bandırma daha fazla rol oynamaya başlamıştır. İstanbul'un ihtiyaç duyduğu bazı mallar doğrudan Bandırma'dan karşılanırken Güney Marmara, Ege ve hatta İç Anadolu'dan karayoluyla Bandırma'ya getirilen mallar yine deniz yoluyla başkente ulaştırılmıştır. Bu özellikleriyle kentin İstanbul açısından çok önemli bir lojistik merkezi olduğu söylenebilir. Bu bağlamda Bandırma ve çevresinden İstanbul'a her türlü tahıl, bakliyat, meyve ve sebze, zeytin ve zeytinyağı, her türlü büyük ve küçükbaş hayvan, deri, hayvan yemleri ve çok çeşitli madenler nakledilmekteydi. Bunun yanı sıra ordunun ihtiyacı için peksimetlik buğday başta olmak üzere zahire, özellikle donanma için kereste, kaba hasır, tersane için funda kömürü ve topların kalıba dökülmesi için çam odunu da İstanbul'a gönderilen mallar arasındaydı. (Çağman, 356)

Emtia sevkiyatının artışına paralel olarak yolculuklarda da artış olduğunu ifade edebiliriz. Rutin yolculukların yanı sıra özellikle Balkan savaşları döneminde askerler ve muhacirlerin taşınmasında yine Bandırma kenti ve limanı çok önemli fonksiyonlar icra etmiştir. (Aslan, 2008: 80)

19. yüzyılın sonlarından itibaren gerek ticari hareketlilik gerek savaşların yol açtı̆̆ göçlerden dolayı Bandırma'nın nüfusu artmış; 1890 yılında 33.000 olan nüfus 1906 yılında 55.000'e çıkmıştır. Nüfusun çoğunluğunu Müslümanlar teşkil etmekle birlikte Rum, Ermeni, Bulgar, 
Katolik ve Protestanların da ciddi bir yekûn oluşturduğu bilinmektedir. (Mutaf, 2003: 83) Bu nedenle Bandırma'nın demografik açıdan çeşitlilik arz ettiği görülmektedir.

\section{Bandırma-İstanbul Denizyolu ulaşımında yaşanan problemler}

Bandırma-İstanbul denizyolu ve Bandırma limanında artan yolcu ve mal hareketliliğine rağmen gerek vapurların sayı ve kalite açısından yetersizliği gerek limanın fiziksel durumunun elverişsizliği nedeniyle ulaşımda bazı aksaklıkların olduğu görülmektedir. Buna zaman zaman meydana gelen rüzgâr ve fırtınanın da olumsuz etkisi ilave edilmelidir. Öte yandan vapurların yetersizliği ve kalitesizliği bazen halkın şikâyetine de konu olmuş ve yetkililerden önlem alınması istenmiştir. 8 Ocak 1894 tarihinde özellikle tüccarlar olmak üzere Bandırma halkı vapurların çürük olması nedeniyle hem insan hayatının tehlikeye atıldığını hem de malların telef olma riskiyle karşı karşıya kaldığını ifade ederek durumu bir arzuhalle Sadarete bildirmişlerdir. Arzuhalde çözüm olarak sağlam ve nezih vapurların seçilmesi gerektiği vurgulanmıştır. Yetkililerin yaptığı araştırmada vapurların iddia edildiği gibi çürük olmadıkları, bazen karantina hizmeti gördüğünden vapur eksikliği yaşandığı ve yeni alınmış olan bir vapurun da yakın zamanda hizmete sunulacağı bildirilmiştir. (BOA, BEO.351.26262.Lef -3/1, 27 Kanun-1 evvel 1309/8 Ocak 1894)

Vapur yetersizliğiyle ilgili bir başka şikâyette ise Bandırma'ya haftada iki defa gelen vapurun küçük olması, diğer vapurların da tüccarlara kiralanması nedeniyle yolcuların eşyalarını götüremediği, çocuklarıyla birlikte perişan halde sokaklarda yatmak zorunda kaldıkları, yolcuların mağduriyetinin giderilmesi ve buna ilave olarak taşınması gereken koyunların sevki için vapur ihtiyacının acilen karşılanması gerektiği belirtilmiştir. Osmanlı Seyr ü Sefain Dairesi problemin vapurların tamamının askeri nakliyata tahsis edilmesinden kaynaklandığını fakat buna rağmen yakın zamanda tamirden çıkacak olan Yörük vapurunun tahsis edilerek haftada iki olan Bandırma-İstanbul sefer sayısının üçe çıkarılacağını ifade etmiştir. (BOA, DH.I.UM.EK.101.47.Lef-1, 23 Mart 1332/5 Nisan 1916; BOA. DH.İ.UM.EK.101.47.Lef 5; 28 Mart 1332/10 Nisan 1916)

1914 yılında Ticaret ve Ziraat Nezareti, Dahiliye Nezareti'ne gönderdiği bir yazıda Bandırma limanının öneminden bahsetmekle birlikte limanın mevcut haliyle ilgili bazı problemlerine değinmiştir. Vapurların karaya yanaşmasının çok uzun sürdüğü, iskelenin kısa olması nedeniyle limana yanaşamayıp açıkta demirlemek zorunda kaldığı ve yolcuların gece karanlığında riskli bir şekilde karaya çıkabildiği ifade edilmiştir. Bu durumun seyahat süresini uzattığı, seferlerin düzenini aksattığı, ticari mal nakliyatının tehlikelere maruz kaldığı ve netice itibarıyla ecnebi vapur şirketlerine talebin arttığı belirtilmiştir. Nezaret, seferlerin talebe uygun ve düzenli yapılması halinde hem taşımacılığın hem de denizyoluna ilaveten demiryoluna rağbetin ve bunlara paralel olarak hazine gelirlerinin artacağını ileri sürerek belediyeye ait olan iskelenin uzatılması ve genişletilmesini gerekli görmüştür. (BOA, DH.ID.197.6.Lef-2/1, 29 Kanun-1 evvel 1329/11 Ocak 1914)

Dönemin Karesi Mutasarrıfı Mazhar Bey de Bandırma-İstanbul denizyolu ulaşımında yaşanan problemler hakkında 1917 yılında yazdığı ayrıntılı bir raporu Dahiliye Nazırı Talat Paşa'ya sunmuştur. Rapordan anlaşıldığına göre o dönemde Bandırma-İstanbul arasında yolculuk yaklaşık yedi-yedi buçuk saat sürmekteydi. Haftada karşılıklı ikişer sefer halinde dört sefer yapılıyor ve vapurlar Bandırma'dan pazartesi ve perşembe, İstanbul'dan da çarşamba ve cumartesi günleri hareket ediyordu. Ayrıca haftada bir defa cuma günü İstanbul'dan ve salı günü de Bandırma'dan bir ekspres vapur çalışıyordu. Fakat 86 kişilik kapasiteye sahip olan ekspres vapur kamarada yolculuğa tahsis edildiğinden sadece İstanbul ve İzmir'in varlıklı 
kesimleri faydalanıyordu. Kamaralı vapur sınırlı sayıda ve varlıklı kişilere hizmet ettiği için geniş yolcu kitleleri, ortalama iki bin kişinin taşındığı diğer vapurlarla seyahat etmek zorunda kalıyordu. Bunların önemli bir kısmı İstanbul'a tarımsal ürünler götürerek satış yapan tüccar kadınlardı. Bu vapurlar İstanbul'dan sabah 9'da hareket etmekteydi. Yolcuların vapura kabulü, eşyaların çokluğu nedeniyle iki saati buluyor ve bu durum yolculuğu katlanılmaz hale getiriyordu. Akşam üzeri dört veya dört buçuk civarında Bandırma limanına ulaşan vapurdan karaya çıkmak ve trene aktarma yapabilmek amacıyla çok büyük bir izdiham yaşanıyor ve yolcular denize düşme, ezilme, hırsızlığa maruz kalma gibi risklerle karşı karşıya kalıyordu. Öte yandan trenlerin kapasitesi de yolcu yoğunluğunu karşılayabilecek düzeyde değildi. Gemiden inen yolcuların büyük çoğunluğu trene binemiyor ve Bandırma' da cami köşelerinde ve sokaklarda perişan bir halde gecelemek zorunda kaliyordu. Bu yolcuların iaşesinin karşılanması da önemli bir problem teşkil ediyordu. Bazen de şiddetli fırtınadan dolayı vapur Bandırma limanına yanaşamıyor, Kapıdağı yarımadasında uygun yerlere sığınmak zorunda kalıyordu. Öngörülemeyen bu tür durumlarda yine yolcular mağdur oluyor kimi zaman biriki gün boyunca açlık ve susuzluk çekiyorlardı.

Raporda belirtildiğine göre Bandırma'dan İstanbul'a gidişte daha büyük zorluklar söz konusuydu. Özellikle Bandırma iskelesinde askeriye tarafından yapılan zahire denetimlerinde yoğun tartışmalar yaşanıyordu. Fakat bu denetimlerin yapılması gerek askeriye gerek yörede yaşayan vatandaşlar açısından büyük önem taşıyordu. Çünkü iaşe için gerekli olan fasulye, yağ vb. ürünler, fiyatların daha yüksek olduğu İstanbul'a götürülüp satışa sunuluyordu. Mazhar Bey'e göre, sayıları iki binden az olmayan tüccar kadınlar bu faaliyetleri dolayısıyla ordunun ve halkın iaşesini zor durumda bırakıyordu. Bu nedenle İaşe Umum Müdüriyeti'nin emri gereğince yolcuların yanlarında götürebilecekleri erzak miktarı sınırlandırılmıştı.

Mazhar Bey, problemleri izah ettikten sonra çözüm için bazı öneriler sunmuştur. Buna göre, İstanbul-Bandırma arasında ekspres seferler haricinde karşılıklı seferlerin sayısı ikiden üçe çıkarılmalıdır. Birinci Dünya Savaşı nedeniyle daha önce var olan denizaltı tehlikesinin o dönemde artık mevcut olmadığını düşünen Mazhar Bey, vapurların gece yarısı hareket etmesi ve öğleden gece yarısına kadar yolcu kabulünün devam etmesi gerektiğini ileri sürmüştür. Yine Mazhar Bey'e göre, vapur limana yanaştığında oluşan izdihamı önlemek için daha önce Bandırma polisine tahsis edilmiş olan ve tamir için İstanbul'a gönderildiği halde alıkonulan motorbotun en kısa zamanda Bandırma'ya iadesi şarttır. Limanda görevli polis sayısı artırılmalı, Bandırma-İstanbul arasında seyahat eden yolculara ait malların yüklenmesi, sevkiyatı, mallar ile zahirenin denetimi ve ayrıca ordunun zahire ihtiyacının karşılanması gibi görevler hükümete terk edilmelidir. Yolcuların nereden ve ne zaman vapura bineceğinin tespit edilmesi görevi ve İstanbul'a sevkiyatı yasaklanacak zahire listesiyle ilgili tedbir ve denetimler mülki ve mahalli idareler tarafından yerine getirilmelidir. (BOA, DH.İ.UM.EK.45.40.Lef-2. Kanun-1 evvel 1333/Aralık 1917)

\section{Deniz ulaşımı kalitesinin artırılması için Bandırma'da yapılan faaliyetler}

1874 yılında Bandırma kent merkezinde vuku bulan yangın çok büyük zararlara yol açmıştır. Yangından sonra hem kent merkezinin hem de liman bölgesinin yeniden düzenlenmesi için bir planlama yapılmıştır. Planlama heyeti, Bandırma'nın gittikçe artan öneminden dolayı özellikle liman yakınındaki bazı caddeleri oldukça geniş tutmuştur. (BOA, ŞD.1537.9.Lef-3, 29 Cemaziye'l-ahir 1292/2 Ağustos 1875)

Deniz ulaşımı hizmetlerinin daha iyi bir şekilde verilebilmesi için yapılan yeniliklerden biri limandaki hizmet binalarıla ilgilidir. 19. yüzyılın sonlarına kadar Bandırma'da liman 
yönetimine ve vapur seferlerini yapan şirkete ait herhangi bir ofis bulunmadığ anlaşılmaktadır. Bu nedenle harcamaları liman yönetimi ve Bandırma-İstanbul güzergâhındaki vapurları işleten İdare-i Mahsusa Şirketi tarafından karşılanmak üzere 1894 yılında Sadaretin emriyle söz konusu kurumlar için birer ofis yapılması kararlaştırılmıştır. (BOA, İ.BH.1.54.Lef-1, 10 Teşrin-i sani 1310/22 Kasım 1894; BOA, İ.BH.1.54.Lef2, 27 Teşrin-i sani 1310/6 Aralık 1894)

20. yüzyılın başlarında Bandırma limanında artan gümrük işlem hacmi nedeniyle mevcut gümrük dairesi ile ambar yetersiz hale gelmiştir. Ticari eşyalar zorunlu olarak limandan uzakta depolanmış ve bu durum çeşitli problemlere yol açmıştır. Limanda yaşanan depolama ile ilgili problemlerin çözümüne yönelik olarak yeni bir gümrük dairesi inşasının zaruri hale geldiği yetkililer tarafından ifade edilmiştir. (BOA, DH.MKT.2378.69.Lef-1/1, 7 Temmuz 1317/20 Temmuz 1901)

Bandırma limanı ve çevresinin önemli eksikliklerinden biri de körfez bölgesinde aydınlatmanın yeterli olmamasıydı. Özellikle kentin yakınında bulunan adalar gece yapılan deniz yolculukları açısından ciddi bir risk oluşturuyordu. Ayrıca denizyoluyla asker sevkiyatı gerektiğinde aynı nedenle gecikmeler yaşanabiliyordu. Bu riski minimize ederek gece yapılan vapur seferlerini daha güvenli hale getirmek amacıyla Bandırma'nın çevresindeki adalara deniz fenerleri inşa edilmesi kararlaştırılmıştır. (BOA, DH.MKT.1036.46.Lef-1/2, 15 Kanun-1 evvel 1321/28 Aralık 1905; BOA. DH.MUİ.119.34.Lef-1-2, 22 Temmuz 1326 /4 Ağustos 1910)

Denizyolunun daha güvenli ve konforlu hale getirilmesi için faaliyetler devam ederken 1912 yılında işletmeye açılan Soma-Balıkesir-Bandırma demiryolu, İstanbul ve Marmara Denizi'yle entegrasyonu sağlamış ve Bandırma kenti ve limanının önemini artırmıştır. Bu sayede bölgedeki tarımsal faaliyetlere ilgi artmış, Ege Bölgesi'nde yetiştirilen ürünlerin nakliyatında demiryolu ön plana çıkmıştır. Ayrıca Aydın, Manisa ve Balıkesir gibi merkezlerdeki madenlerin sevkiyatı da hız kazanmıştır. (Köç, 2018: 381-382)

\section{Bandırma-İstanbul vapur yolcu listeleri}

Bandırma-İstanbul arasında sefer yapan vapurlara ait yolcu listeleri, 17 Nisan 1331-17 Teşrini Sani 1334 (30 Nisan 1915-30 Kasım 1918) tarihleri arasında değişkenlik gösteren 11 farklı vapur yolculuğundan ve toplamda 23 belgeden (2) oluşmaktadır. Listeler sadece Bandırma'dan İstanbul'a yapılan yolculukları kapsamaktadır. İstanbul'dan Bandırma'ya yapılan yolculuklarla ilgili liste sayısı ise çok az olup karşılaştırma yapabilmek için yeterli ve elverişli değildir. Bu nedenle çalışmaya dahil edilmemiştir. Aslında Bandırma'dan İstanbul'a yapılan seferlere ait listelerin de üç yıllık zaman dilimi göz önüne alındığında değerlendirme için yeterli olduğu pek söylenemez. Öte yandan bu listeler bir seri teşkil edecek nitelikte de değildir. Fakat kısıtlı sayıda ve dağınık olmakla birlikte yine de bazı analizlere konu olabilecek özelliklere sahiptir. Listeler bize yolcuların isimleri, yaşları, cinsiyetleri, memleketleri, uyrukları, meslekleri, nereden geldikleri ve İstanbul'da nerede konaklayacakları (otel, han, özel mesken vb) hakkında bilgi vermektedir. Bazılarında biletlerin nereden temin edildiği ve hangi vapurla yolculuk yapıldığı ifade edildiği halde, bazılarında bu bilgiler bulunmamaktadır.

Yolcu listelerinin bir kısmında vapurların yolculuk tarihi yazmamakla birlikte biletlerin satın alındığı tarihlerden yola çıkarak yaklaşık bir tahmin yapılabilmektedir. Az sayıda bazı listelerin yolcuların mensup oldukları dinlere göre düzenlendiği görülmektedir. Tüm yolcuların genel yaş ortalaması 40 civarındandır. Bu ortalama Müslümanlar ve gayrı Müslimler için aynıdır. 13 yaşın altında herhangi bir yolcu kaydına tesadüf edilmemektedir. 
Yolcuların tamamının çocuksuz seyahat etmesi pek mümkün görünmediğinden bu durum, belirli bir yaşın altında ve ebeveyni ile birlikte seyahat eden çocukların muhtemelen ücrete tabi olmadığını yani onlar için ayrıca bir bilet alınmasının zorunlu olmadığını ve bu nedenle listelerde zikredilmediğini düşündürmektedir. Vapur başına düşen yolcu sayısı 58'dir. Ayrıca listeler karşılaştırıldığında mükerrer yolculuklara rastlanmamaktadır. Yani aynı kişilerin farklı zamanlarda seyahat ettiği görülmemektedir.

Listelerden anlaşıldı̆̆ına göre bazen Sirkeci'ye bazen de Galata'ya yolcu indiren vapurların isimleri Paşabahçe, Kısmet, Armağan, Reşid Paşa, Bandırma, Nimet, Gülnihal ve Yörük'dür.

(3) Yolcular, biletleri ilgili kaza komiserliklerinden, polis müdüriyetlerinden, kaymakamlık ve tabur kumandanlıklarından temin edebilmektedir. Bandırma'dan denizyoluyla İstanbul'a gidecek yolcuların biletlerini aldıkları merkezler arasında Bandırma'nın yanı sıra; Bursa, Aydın, İzmir, Balıkesir, Isparta, Burdur, Ayvalık, Lapseki, Biga, Edremit, Soma ve Bergama'yı sayabiliriz. (4) Bununla birlikte biletlerin temin edildiği yerler bazı listelerde belirtilmemiştir. Çalışmada kullandığımız listelere göre 11 farklı seferle toplam 643 yolcu Bandırma'dan denizyoluyla İstanbul'a seyahat etmiştir. (5) Yolcuların 537'si erkek, 106'sı kadındır. Listelerdeki meslekleri/sanatları bölümünde erkeklerin yaptıkları işler kaydedilmişken kadınlar için bazen açıkça "Nisa" kelimesiyle, bazen de "Nun" harfiyle sadece cinsiyetleri belirtilmiştir. İsimlerinden yola çıkarak yaptığımız tespite göre yolcuların 403'ü Müslüman, 240 '1 gayrimüslimdir. Gayrimüslimlerden 172 'si erkek, 68' $\mathrm{i}$ ise kadındır. Gayrimüslim yolcu sayısı toplam yolcuların \%33'ünü teşkil etmesine rağmen gayrimüslim kadınların Müslüman kadınlara oranla çok daha fazla olduğu görülmektedir. Listelere göre seyahat eden gayrimüslim kadınların sayısı 73 iken Müslüman kadınların sayısı 33'tür.

Listelerin bazılarında iki ayrı sütunda yolcuların memleketleri ve geldiği yer (mevrudu) kaydedilmişken bazılarında ise doğduğu yer ile geldiği yer kayıtlıdır. Fakat doğduğu yer hanesi boş bırakılmış olup sadece geldiği yer belirtilmiştir. Birinci tür belgelerden bu yolcuların Trakya ve Balkanlardan Karadeniz ve hatta İç Anadolu'ya kadar çok farklı coğrafyalarda doğdukları veya o bölgelere mensup oldukları anlaşılmaktadır. Fakat bununla birlikte geldiği yer bölümünün tamamına yakınında Bandırma kaydı bulunmaktadır. Bu kayda rağmen söz konusu tüm yolcuların Bandırmalı olması mümkün görünmemektedir. Mevrudu bölümündeki Bandırma kaydını vapura binilen yer olarak kabul etmek daha makuldür. Bu şekilde tutulan listelerdeki toplam 160 yolcunun 17'si İstanbullu, 13'ü Gönenli, 11'i Selanikli, 7'si Sirozlu'dur. Geriye kalanlar ise sayıca büyük gruplar teşkil edemeyecek derecede farklı yerlerden gelenlerdir. Bu listelerden söz konusu kişilerin nerede ikamet ettiğine dair bilgiye ulaşmak mümkün değildir.

İkinci grubu oluşturan listeler bize daha net bilgiler vermektedir. Çünkü bu listelerdeki mevrudu bölümünde sadece Bandırma değil civar bölgelerin isimleri de belirtilmektedir. Buradan hareketle mevrudu Bandırma yazanların kentte ikamet ettikleri, kaydedilmiş olan diğer merkezlerin ise İstanbul'a gitmek amacıyla Bandırma'ya gelenlerin ikamet ettikleri yerler olduğu sonucunu çıkarabiliriz. Bu tarz tutulan listelerde toplamı 483 olan yolcuların yarıdan biraz fazlası Bandırma'da yaşamaktadır (256 kişi, \%53). Bunu 76 kişiyle (\%15) İzmir' den gelenler izlemektedir. Ardından Karesi' den (43 kişi, \%9) ve Burdur' dan gelenler (22 kişi, \%4.5) önemli bir yekûn teşkil etmektedir.

Bandırmalı yolcuların 52'si tüccar, 51'i kadın, 15'i öğrenci, 10'u bakkal, 5'i üst düzey bürokrat, 9'u memur, 8'i rençber ve zürradır. Bunların dışında çok az sayıda tütüncü, balıkçı, kahveci, terzi, kayıkçı, mühendis, çoban, kunduracı gibi farklı meslekleri icra eden kişiler bulunmaktadır. İkamet yeri olarak 90 kişi oteli, 86 kişi bir akraba veya yakınının hanesini, 5 
kişi hanları tercih etmiştir. Ayrıca 36 kişinin kendi hanesinde kaldığı 7 kişinin Bandırma'ya döneceği veya İstanbul' dan başka bölgelere gideceği anlaşılmaktadır. Bunların dışında çok az sayıda yolcu kahve, okul ve dükkân gibi mekânlarda konaklamaktadır.

\section{Yolcuların İstanbul'da kaldı̆̆ı mekânlar}

Listelerde yolcuların kalacakları yerler belirtilmiş olup değişik mekânlarda konakladıkları anlaşılmaktadır. 643 yolcunun büyük bölümü hane ve otelleri tercih etmiştir. Yolcuların 293'ü hanelerde, 265 kişi otelde, 45 kişi kahve, dükkân, mağaza, yatılı okul gibi çeşitli yerlerde, 20'si hanlarda kalmıştır. Bunun dışında 20 kişi ise ya aynı gün Bandırma' ya döneceğini ya da başka bir bölgeye seyahat edeceğini bildirmiştir. Yolcuların kaldıkları mekânlarla statüleri, meslekleri ve gelirleri arasında bir iki otel dışında bir ilişki kurabilmek pek mümkün olmamaktadır. Bu bağlamda her ne kadar bazı tüccarların nispeten daha lüks olarak nitelendirebileceğimiz apartmanlarda kaldığı kayıtlı ise de buna mukabil manav, posta memuru, rençber, makinist gibi kişilerin köşk ve konaklarda kaldığı da vakidir.

\section{Haneler}

Yolcuların yarısına yakınının haneleri (293; \%45) tercih ettiği görülmektedir. Aralarında çok az sayıda apartman, konak ve köşklerin de bulunduğu haneler açık adresleri, semt ve sokak isimleri, bazen de kapı numarasına varıncaya kadar ayrıntılı şekilde listelerde yer almıştır. Haneler yolcunun kendisine ait ise hanesi, değilse sahibi olan şahsın hanesi, apartmanı veya konağı olarak belirtilmektedir.

Hanelerin büyük çoğunluğu başkalarına aittir. Herhangi bir hanede kalan 293 yolcudan ancak 79'unun kendisinin veya ebeveyninin mülkiyetinde ikamet ettiği anlaşılmaktadır. Az sayıdaki bu kişilerin aslen İstanbul'da ikamet edip çeşitli nedenlerle ve belirli süreliğine Bandırma veya çevresine gittikleri ve daha sonra geri döndükleri kabul edilebilir. Ev sahibi yolculardan 15'i kadındır. Meslek dağılımı açısından 11'i tüccar, 7'si tütüncü veya tütün bayi, 5'i öğrencidir. Bunların dışında çok farklı fakat dağılım açısından grup oluşturamayacak sayıda mesleklerin de listelerde yer aldığı görülmektedir.

\section{Oteller}

Oteller bulundukları semtlerin adlarıyla birlikte kaydedilmiştir. İstanbul'da Sirkeci, Galata, Beyoğlu ve Fatih olmak üzere dört farklı semtte bulunan oteller tercih edilmiş olup konaklayan yolcu sayısı 265 (\%41)'dir. Listelerde belirtilen sayılara göre Bandırma'dan denizyolunu kullanarak İstanbul'a gelen yolcuların kaldığı otellerin çoğu Sirkeci'de bulunmaktadır. Bunlardan en çok tercih edileni 26 kişiyle Meserret Oteli'dir. Bu yolcuların büyük çoğunluğunu başta tüccarlar olmak üzere terzi ve bakkaldan sihhiye memuru ve müfettişine, berberden manifaturacıya ve kadın yolculara kadar farklı kesimlerden insanlar teşkil etmektedir. Meserret Oteli'nden sonra en çok tercih edileni Meşrutiyet Oteli'dir. Yine büyük çoğunluğu tüccarlar olmak üzere kaymakam, mahkeme üyesi ve müteahhit gibi şahısların da bulunduğu 22 yolcu bu otelde kalmıştır. Yolculardan 20'si ise Sirkeci'de Bahr-1 Sefid Oteli'nde konaklamıştır. Aralarında fabrikatör, dava vekili, reji memuru gibi yüksek statüye mensup kişilerle çok sayıda tüccarın dışında, kunduracılık, bakkallık ve kayıkçılık gibi mesleklerle iştigal eden şahıslar bulunmaktadır. Sirkeci'deki söz konusu üç oteli Bandırma (9 kişi) ve Filibe Oteli (8 kişi) takip etmektedir.

Galata'da en çok tercih edilen oteller ise 13'er yolcu ile Bandırma ve Olimpiya Otelleridir. Ardından 10 kişi ile Ankara Adapazarı Oteli gelmektedir. Bandırma Oteli'nde 
konaklayanların 9'u tüccar, 3'ü kadın ve biri sarraf iken Olimpiya ve Ankara Adapazarı otellerindeki yolcuların mesleki açıdan çeşitlilik arz ettiği görülmektedir. Beyoğlu'nda en çok rağbet gören ise 10 kişi ile Tokatlıyan Oteli'dir. Ardından gelen 9 oteldeki yolcu sayısı çok az olup bu semtte otel başına düşen yolcu sayısı ikinin altındadır. Otel sayısı açısından en az tercih edilen semt ise Fatih'tir.

\section{Sirkeci}

Listelerden anlaşıldığına göre yolcular Sirkeci'de 40 farklı otelde konaklamaktadır. (6) Bu oteller; Altay Oteli, Anadolu Oteli, Ankara Adapazarı Oteli, Aydın Oteli, Bahr-1 Sefid Oteli, Bandırma Oteli, Berlin Oteli, Bizans Oteli, Bursa Oteli, Bursa Merkez Oteli, Bosna Oteli, Cumai Atik Oteli, Deniz Oteli, Edirne Oteli, Filibe Oteli, Haleb Oteli, İkbal Oteli, İskenderiye Oteli, İzmir Oteli, İzmit Oteli, Kala-yı Sultaniye Oteli, Manastır Oteli, Marbeçe Oteli, Marmiha Oteli, Mehmed Efendi Oteli, Merkez Oteli, Meserret Oteli, Meşrutiyet Oteli, Osmaniye Oteli, Osmanlı Oteli, Paris Oteli, Posta Oteli, Rumeli Oteli, Santral Otel, Selanik Oteli, Silistre Oteli, Şark Oteli, Tekfurdağı Oteli, Trabzon Oteli ve Viyana Oteli'dir.

\section{Galata}

Yolcuların Galata'da konakladıkları otellerin sayısı 15'tir. (7) Bunlar; Anadolu Oteli, Ankara Adapazarı Oteli, Bandırma Oteli, Berlin Oteli, Bursalı Oteli, Edirne Oteli, Mürefte Oteli, Metropol Oteli, Olimpiya Oteli, Osmaniye Oteli, Tekfurdağ 1 Oteli ve Yorasalem Oteli'dir.

\section{Beyoğlu}

Beyoğlu'nda konaklanan otellerin sayısı 11'dir. Bu oteller; Emir Bey Oteli, Emperyal Oteli, Hiryoyal Oteli, Kordon Oteli, Metropol Oteli, Otel Koru, Pera Palas Oteli, Peter Oteli, Prepandis Oteli, Sanrar Oteli ve Yeni Şark Oteli'dir.

\section{Fatih}

Yolcuların Fatih'te kaldığı oteller, Bosna Hersek Oteli, Mahmutpaşa Oteli ve Konya Oteli'dir. Bunların dışında yolcuların Fatih'te konakladıkları 3 otel daha bulunmaktadır. (8)

\section{Kahve ve dükkânlar}

Yolcuların hane, otel ve hanların dişında sırasıyla en çok muhtelif yatılı okullarda, kahve, dükkân veya mağazalarda kaldıkları görülmektedir (45 kişi; \%7). Belgelerdeki ifadelerden bu tür yerlerde kalan yolcuların bir kısmının bu mekânların sahipleri olduğu anlaşılmaktadır.

\section{Hanlar}

Gelen yolcuların konaklama açısından en az tercih ettiği mekânlar hanlardır. (20 kişi, \%3) Sayısı 20 olan bu hanlar; Balıkpazarında Nevşehir Hanı, Kantarcılarda Yeni Han, Sultanhamamında Müsavat Han, Yağ kapanında Lazlar Hanı, Çakmaçılarda Çukur Han, Mercan'da Kehribarcı Han, Sirkecide Yeni Han, Köprücü Han, Fatih'te Destur Han, Sultanhamam'da Meserret Han, Havyar Hanı, Tahtakalede Şehzade Han, Türbedar Hanı, Valide Han, Şeyh Hanı, Beyoğlunda Taksim Habaye Hanı, Doğriyol'da Hazeryan Han, Nişantaşı Firuze Han, Südlüce Saatcibaşı İsmail Efendi Hanı, Pangaltı'da Altun Bakkal sokağında Azanik Hanı'dır. 


\section{Yolcuların meslekleri}

Listelerde meslek/sanat bölümünde kadın yolcuların sadece cinsiyetleri yazmakla birlikte erkek yolculardan bir-iki istisna haricinde tümünün meslekleri kaydedilmiştir. Bu bağlamda erkek yolcuların çok farklı meslek gruplarına dahil olduğu görülmektedir. Meslekler içinde ticaretle iştigal edenlerin sayısı açık ara ile diğerlerinden öndedir (169 kişi,\%31). Tüccarların 105 'i Müslüman, 64'ü ise gayrimüslimdir.

Yolcular içinde çok büyük bir yekûn teşkil etmesine rağmen İstanbul'da hane sahibi olan tüccarların sayıca az olduğu görülmektedir. Tüccarların büyük çoğunluğunun otel ve hanlarda kalması, bu meslek grubuna mensup olanların Bandırma ve çevresinden İstanbul'a ticari nedenlerle ve geçici süreliğine geldiklerini düşündürmektedir. Benzer şekilde diğer meslek sahiplerinin de işleri gereği ve yine geçici süreyle İstanbul'a geldikleri yorumunu yapmak mümkündür.

Tüm yolcular arasında tüccarlardan sonra en yoğun grubu 27 kişi ile öğrenciler teşkil etmektedir. Ardından 26'şar kişi ile bakkallar ve rençberler ile gelmektedir. Bu meslek gruplarında Müslümanların sayısı gayrimüslimlere göre üç ila dört kata yakın oranda fazladır. Bunları 24 kişi ile aralarında vali, kaymakam, mahkeme reisi, istinaf mahkemesi azası, sıhhiye müfettişi, Bandırma mal müdürü ve Karesi meclis-i umumi azası gibi üst düzey bürokratların bulunduğu meslek grupları takip etmektedir. Daha sonra 14'er kişiyle memurlar ve kahveciler, 12 kişiyle çeşitli işlerde çalışan kâtipler gelmektedir. Bu meslek gruplarının dışında, mensuplarının sayısı 10 veya daha az olan çok farklı mesleklerden kişiler mevcuttur. Bu mesleklerden bazıları şöyle sıralanabilir: Tütüncü, demiryolcu, kunduracı, balıkçı, çoban, marangoz, müderris, mühendis, manav, muallim, bahçıvan, kayıkçı, sarraf, bezzaz, koltukçu, komisyoncu. Bunun yanında her birine sadece birer yolcunun mensup olduğu meslekler de söz konusudur.

Müslümanlar arasında ticaretten sonra en yoğun meslek gruplarını bakkallar, öğrenciler, rençberler, üst düzey bürokratlar, memurlar, kahveciler, devlette veya özel sektörde kâtiplik yapanlar ve tütüncüler oluşturmaktadır. Gayrimüslim yolcular arasında ise çoğunlukla yine ticaretle iştigal edenlerden sonra sırasıyla öğrenci, balıkçı, bakkal, rençber yer almakta ve Müslümanlarda olduğu gibi farklı mesleklerin yaygın olduğu görülmektedir. Yolcular içinde istisna kabul edilebilecek sayıda işsiz ve mesleği belirtilmeyen kişiler mevcuttur. Listelerin büyük ihtimalle ekspres vapurlara ait olduğu ve Karesi Mutasarrıfı Mazhar Bey'in raporunda verdiği bilgiye göre ücretinin diğer vapur ücretlerinin iki katı olduğu göz önüne alınırsa bu yolcuların ekonomik olarak diğer vapurları tercih edenlerin üzerinde bir gelire sahip olduğu tahmin edilebilir. Bunun yanı sıra tüccar yolcuların, üst düzey bürokratların ve sarrafların, maden sektöründe çalışanların, özel sektör yöneticilerinin de göreceli olarak ekonomik açıdan diğer meslek gruplarına göre daha iyi durumda olduğunu söyleyebiliriz.

\section{Sonuç}

Bandırma coğrafi konumu ve İstanbul'a yakınlığı nedeniyle antik dönemlerden itibaren önemli bir kent olma özelliğini sürdürmüştür. Osmanlı döneminde özelikle 19. yüzyıldan itibaren hareketliliği gittikçe artan Bandırma, İstanbul'un hayvancılık, ziraat, sanayi ve askeriye açısından ihtiyaç duyduğu birçok ürünün tedarik edildiği bir merkez olmuştur. Bu nedenle Bandırma-İstanbul denizyoluyla hem ürün hem de insan taşımacılığ 1 yoğun bir faaliyet haline gelmiştir. Fakat artan bu yoğunluğa rağmen verilen hizmetlerin zaman zaman aksadığ1 ve şikâyetlere konu olduğu görülmektedir. Bu nedenle ulaşımın ihtiyaca cevap verebilmesi için Bandırma ve çevresinde bazı faaliyetlere girişilmiştir. 1874 yangınından 
sonraki imar faaliyetleri esnasında kentin yakın zamanda daha fazla büyüyeceği düşünülerek limana yakın caddeler özellikle geniş tutulmuştur. Daha sonra Bandırma limanı genişletilmiş, iskele büyütülmüş, ayrıca gece seferlerindeki riski azaltmak amacıyla belirli yerlere deniz fenerleri inşa edilmiştir. 1912 yılında Soma-Balıkesir-Bandırma demiryolunun hizmete açılmasıyla denizyolu ile demiryolu entegre edilmiş ve böylece birçok yönden Bandırma'nın gelişmesi hedeflenmiştir.

Çalışmanın ikinci bölümünde Bandırma'dan İstanbul'a yapılan bazı vapur seferlerine ait yolcu listeleri ele alınmıştır. Söz konusu listeler sayıca az ve üç yıllık bir döneme yayılmış olup bir seri teşkiline imkân vermemektedir. Fakat buna rağmen yine de bu listeler bazı önemli bilgileri içermekte ve kısmen de olsa analiz yapmamıza imkân tanımaktadır. Bu tür belgelerin daha fazla mevcudiyeti halinde daha sağlıklı karşılaştırma ve değerlendirmeler yapılabilmesi mümkün olacaktır.

Yolcu adlarının listelerde yer alması sayesinde dini cemaatlere mensubiyet açısından dağılım yapılabilmektedir. Buna göre yolcuların \%63'ünün Müslüman, diğerlerinin ise gayrimüslim olduğu anlaşılmaktadır. Kadın yolcuların cinsiyetlerinin kaydedilmiş olması nedeniyle onların da hem toplam sayılarına hem de dini mensubiyetlerine ait verilere ulaşılabilmektedir. Erkek yolcular arasında Müslümanların gayrimüslimlere göre çok fazla olmasına karşın kadın yolcularda bu durum tam aksinedir. Müslüman kadınların sayısı 33 iken gayrimüslim kadınların sayısı 73'tür.

Listelerde yolcuların İstanbul'da kalacakları yerler belirtildiği için bazı otel ve hanların isimlerine ulaşmak mümkün olmaktadır. Otel ve hanlarda kalan yolcuların çokluğu, misafir kalınan hanelerin büyük bölümünün başkalarına ait olması ve listelerde gelinen yer hanesinde Bandırmalı sayısının diğer şehir ve kasabalara göre daha fazla olması gibi olgulara dayanarak yolcuların azamisinin Bandırma' da ikamet ettiği, diğerlerinin de İstanbul'a gitmek üzere çevre kentlerden Bandırma limanına geldikleri tahmin edilmektedir.

Listelerde yer alan bir başka bilgi türü de mesleklerdir. Buna göre çok farklı mesleklere mensup kişilerin Bandırma-İstanbul arasında seyahat ettiği görülmektedir. Yolcu profilleri, meslekler ve kalınan yerler göz önünde alındığında yapılan seyahatlerin mesleki gayeyle ve belirli süreliğine yapıldığ 1 sonucuna varılabilir. Dini mensubiyetlerle meslekler arasındaki ilişkiye bakıldığında herhangi bir meslekte bu açıdan bariz bir yoğunlaşmanın olmadığı ve her iki grubun hemen hemen aynı meslekleri icra ettikleri söylenebilir. Sadece üst düzey bürokratların Müslüman olması bu genelleme için istisna teşkil etmektedir.

Yolcuların büyük çoğunluğunu tüccar kesimi oluşturmaktadır. Buna paralel olarak İstanbul için Bandırma'dan çok çeşitli ürünlerin tedarik edildiği göz önüne alındığında iki bölge arasında çok önemli bir hareketliliğin olduğunu söylemek mümkündür. Çok farklı şehirlere mensup ve yine farklı meslekleri icra eden kişilerin denizyoluyla İstanbul'a gitmek üzere Bandırma'yı sıklıkla kullanmaları da buna ilave edilmelidir. Bu durum Bandırma'nın coğrafi konumunun ve 19. yüzyıl boyunca Bandırma ve İstanbul arasında artan ilişkilerin bir neticesidir.

\section{Açıklamalar}

(1) Osmanlı modern dönemi Bandırma-İstanbul denizyolu ulaşımıyla ilgili ayrıntılı bilgi için (Çağman, 2018: 355-387)

(2) Yolcu listelerini içeren belgeler Başkanlık Osmanlı Arşivleri (BOA) DH.EUM.SSM'de bulunmaktadır. Çalışmada, belgelerdeki sayı ve bilgiler bir arada değerlendirildiği için belgelerle ilgili künyeler metin içinde gösterilmeyip Kaynakça bölümünde verilmiştir.

(3) Mazhar Bey'in raporuna göre Bandırma-İstanbul arasında yolcu kapasitesi ve konfor açısından iki tür vapurun sefer yaptığını daha önce ifade etmiştik. Bunlardan birincisi 86 kişi kapasiteli ve kamaralıdır. İkincisi ise iki bin civarında kapasiteye sahiptir. Çalışmaya konu olan listelerde yolcu sayısının vapur başına yüz civarında olması ve yolcuların önemli bölümünün üst ve orta düzey bürokratlarla tüccarlardan meydana gelmesi bu listelerin ekspres vapurlara aidiyetine dair kanaati güçlendirmektedir. Buna ilave olarak listelerde daha önce Mazhar Bey'in belirttiği çok sayıda kadın (tüccar) a tesadüf edilmemesi de bu durumu teyit 
eder görünmektedir. Fakat bununla birlikte listelerde adı geçen vapur isimlerinin rutin olarak sefer yapan vapurlara ait olması vapur türleri hakkında ihtiyatlı davranmamıza neden olmaktadır.

(4) Bandırma'dan İstanbul'a sefer yapan vapur listelerinin üst kısmında "Bandırma'dan Dersaadet'e gelen" ibaresi bulunmakla birlikte İstanbul' dan Bandırma'ya gelen bir vapur yolcu listesinde "Bandırma İzmir hattına gidenler" şeklinde ibareye tesadüf edilmiştir. Bu durumda vapurun İstanbul-Bandırma-İzmir hattında çalıştığı düşünülebilirse de söz konusu dönemde İzmirBalıkesir-Bandırma demiryolunun işlemekte olduğu göz önüne alındığında İzmir, Aydın, Manisa, Isparta, Balıkesir, Burdur gibi civar bölgelerdeki yolcuların Bandırma'ya geliş-gidişlerinde demiryolunu kullandıklarını kabul etmek daha makul görülmektedir.

(5) DH.EUM.SSM.67.59.Lef 29-2' deki belgedeki listede her ne kadar "Yörük vapuruyla Karadeniz'den gelen yolculardır" şeklinde ibare olsa da yolcuların geldiği bölgelerin Karesi, Bandırma, Erdek, Edincik, Karacabey, İzmir, Akhisar, Burdur ve Kırkağaç olarak kaydedilmesi göz önüne alınarak sehven Karadeniz olarak yazıldığı düşünülmüş ve vapurun Bandırma'dan İstanbul!a gittiği tahmin edilerek ilgili belge çalışmaya dahil edilmiştir.

(6) İstanbul'daki otelleri konu edinen bir makalede 19. yüzyılın sonları ve 20. yüzyılın başlarında Eminönü'nde bulunan otel sayısının 28 olduğu ileri sürülmektedir. Söz konusu çalışmada Sirkeci'deki oteller ayrıca belirtilmediği için bu bölgedeki otellerin de Eminönü içinde değerlendirildiğini düşünmek makul görülmektedir. Çalışmada Eminönü'ne ilave olarak aynı dönemde Kadıköy, Boğaziçi, Adalar, Galata ve Pera' da bulunan otel sayıları da verilmiştir. (Yakartepe-Binan, 92) Fakat Bandırma-İstanbul denizyolunu kullanan yolcularla ilgili belgelerden edindiğimiz bilgiye göre Sirkeci'deki mevcut otellerin sayısı 40'ı bulmaktadır. Listelerde Eminönü ayrıca zikredilmediği için bu semtteki otellerin de Sirkeci içinde değerlendirildiği düşünülebilir.

(7) Sirkeci'de bulunduğu belirtilen bazı otel isimlerine Beyoğlu'nda da tesadüf edilmektedir. Yolcu listelerinde otellerin isimlerinden önce bulundukları semt adları zikredilmektedir. Bu durum dikkate alınarak hem Sirkeci'de hem de Galata'da bulunduğu belirtilen aynı isimli oteller, tarafımızca farklı oteller olarak sınıflandırılmıştır.

(8) Konaklanan otellerden üç tanesinin adı maalesef okunamamıştır.

\section{Kaynakça}

\section{Başkanlık Osmanlı Arşivleri (BOA)}

BEO.351.26262.Lef-3/1, 27 Kānûn-1 Evvel 1309 (8 Ocak 1894)

DH.EUM.SSM.1.20.Lef-1, 15 Cemaziyel ahir 1333 (30 Nisan 1915)

DH.EUM.SSM.3.50.Lef 4, 5, 6, 7, 26 Safer 1334 (3 Ocak 1916)

DH.EUM.SSM.3.75.Lef-1 ve Lef-2, 24 Rebiulevvel 1334 (30 Ocak 1916)

DH.EUM.SSM.4.2.Lef-1, 2 Rebiulahir 1334 (7 Şubat 1916)

DH.EUM.SSM.5.12.Lef-1/1 ve Lef-1/2, 11 Cemaziyelahir 1334 (15 Nisan 1916)

DH.EUM.SSM.5.17.Lef-2, 12 Cemaziyelahir 1334 (16 Nisan 1916)

DH.EUM.SSM.67.55.Lef-1/1, Lef-1/2, Lef-1/3, 13 Safer 1337 (18 Kasım 1918)

DH_EUM.SSM.67.59.Lef-6/1, Lef-14/1, Lef-4/2, Lef-14/3, Lef-29/1, Lef-29/2, Lef-31/1, Lef-31/2,

25 Safer 1337 (30Kasım 1918)

DH.I.UM.EK.101.47.Lef-1 ve Lef-5 28 Mart 1332 (10 Nisan 1916)

DH.İ.UM.EK.45.40.Lef-2. Kānûn-1 Evvel 1333 (Aralık 1917)

DH.íD.197.6.Lef-2/1, 29 Kānûn-ı Evvel 1329 (11 Ocak 1914)

DH.MKT.2378.69.Lef-1/1, 7 Temmuz 1317 (20 Temmuz 1901)

DH.MKT.1036.46.Lef-1/2, 15 Kanun-1 Evvel 1321 (28 Aralık 1905)

DH.MUİ.119.34.Lef-1 ve Lef-2, 22 Temmuz 1326 (4 Ağustos 1910)

İ.BH.1.54.Lef-1 ve Lef-2, 27 Teşrîn-i Sâni 1310 (\& Aralık 1894)

ŞD.1537.9.Lef-3, 29 Cemâziye'l-âhir 1292 (2 Ağustos 1875)

\section{Diğerleri}

Aslan, Sezer. (2008), Balkan Savaşları Sonrası Rumeli'den Türk Göçleri ve Osmanlı Devleti'nde İskânları, Trakya Üniversitesi Sosyal Bilimler Enstitüsü (Basılmamış Yüksek Lisans Tezi), Çağman, Engin. (2018), “Osmanlı Devleti'nin Son Döneminde Bandırma-İstanbul Denizyolu Ulaşımı”, Ed. Ulaş Töre Sivrioğlu, Bandırma ve Yakın Çevresi Tarihi, Bursa, Dora Yayınları, s. 355-387

Köç, Ahmet. (2018) “Bandırma Kazası' nın İzmir-Kasaba Demiryolu Hattına Bağlanması”, Ed. Ulaş Töre Sivrioğlu, Bandırma ve Yakın Çevresi Tarihi, Bursa, Dora Yayınları, s. 371-386

Üçışık, Süheyla. (1998), Bandırma Şehir Coğrafyası, Marmara Üniversitesi Sosyal Bilimler Enstitüsü, Coğrafya Anabilim Dalı (Basılmamış Doktora Tezi) 
Yakartepe, E.Ç.- Can, B. (2011), İstanbul'un Modernleşme Dönemi Otelleri (1840-1914), 3 Ekim 2020 tarihinde http://www.journalagent.com/megaron/pdfs/MEGARON_6_2_79_94.pdf, adresinden alınd1.

Ek 1. 5 Teşrin-i sani 1334 tarihinde Bandırma'dan İstanbul'a gelen vapur yolcularının listesi

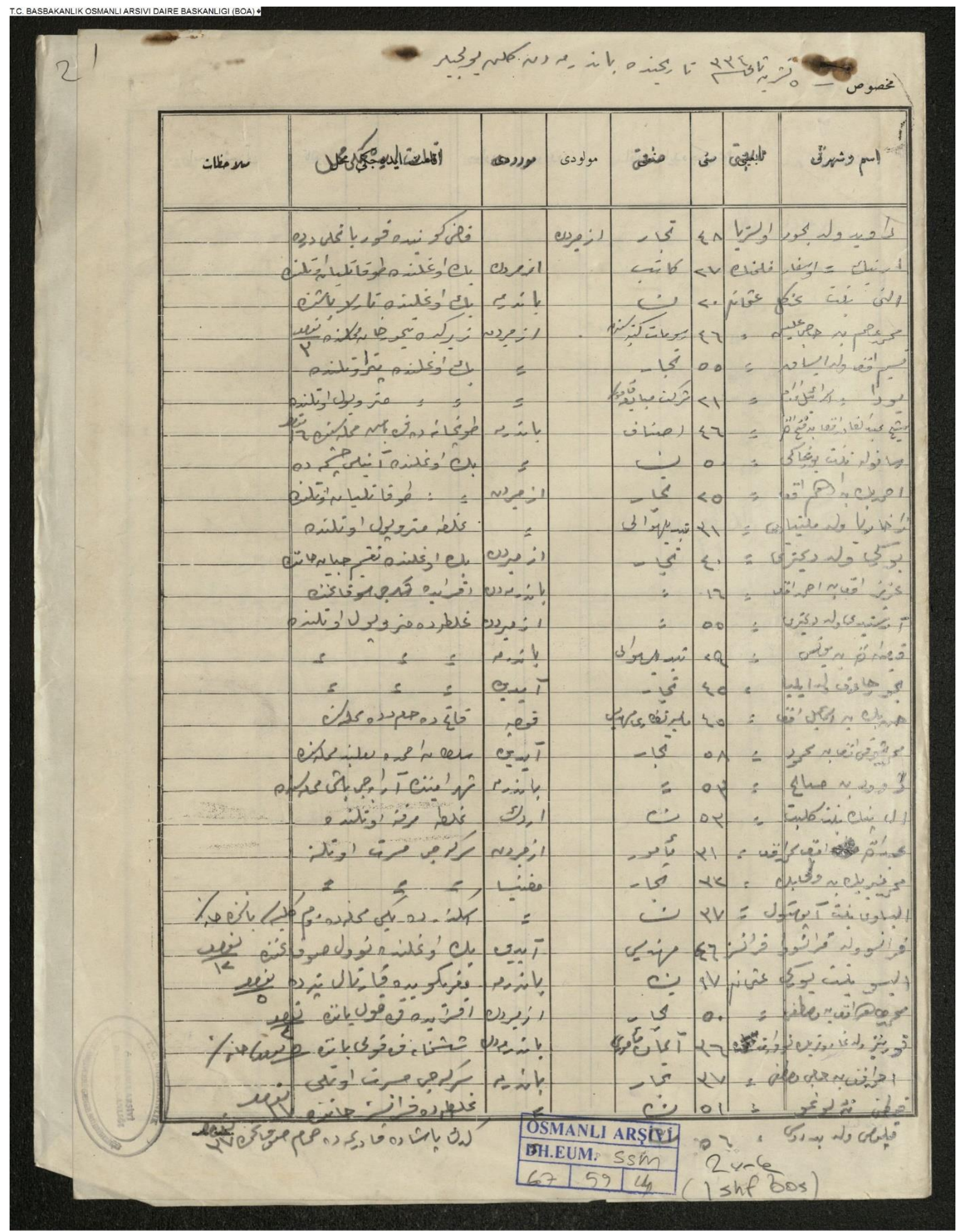

DH.EUM.SSM.00067.00059.014 
Ek 2. 17 Teşrin-i sani 1334 tarihinde Bandırma'dan İstanbul'a gelen vapur yolcularının listesi

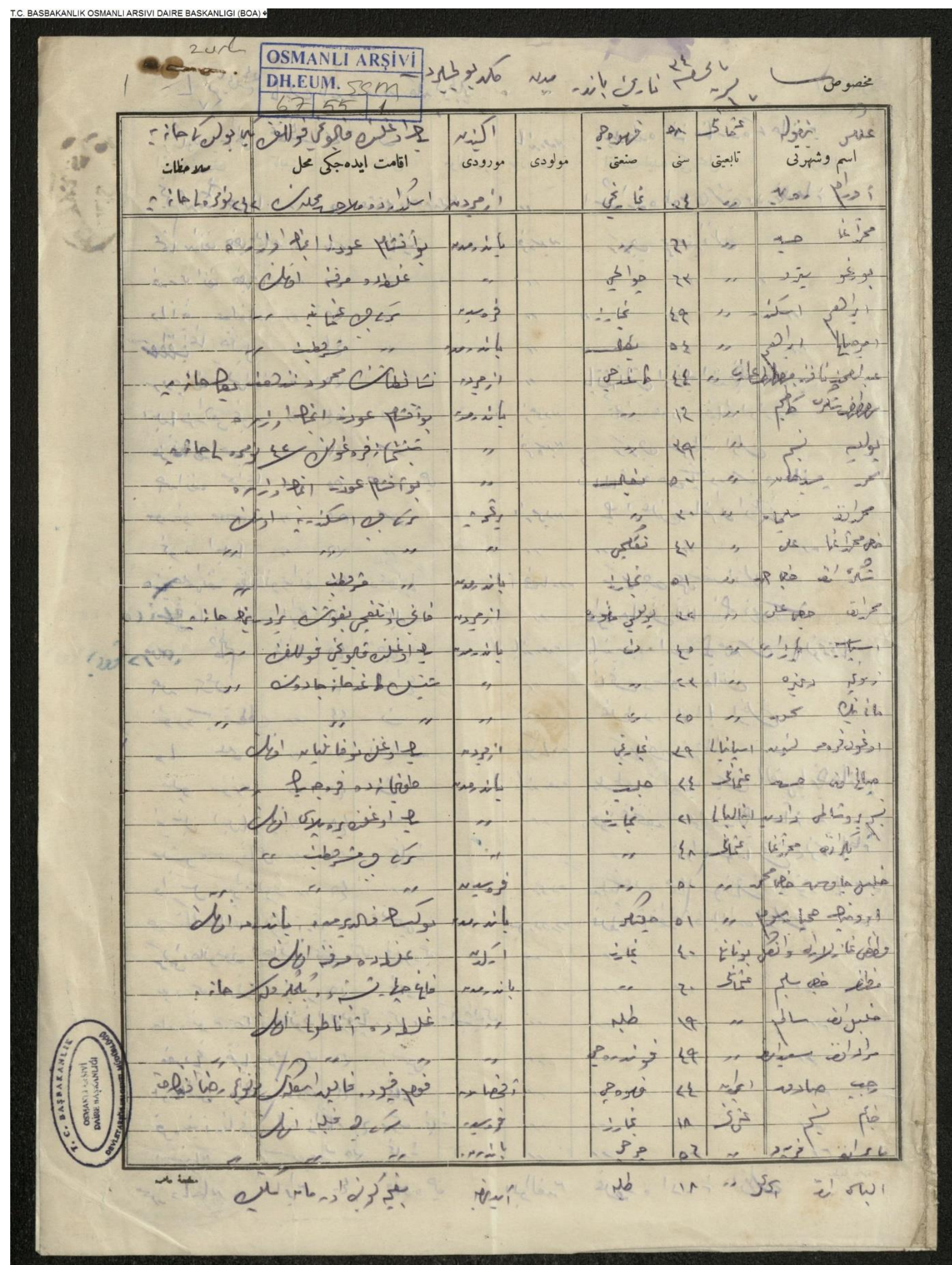

DH.EUM.SSM.00067.00055.001 